\title{
Intravenous infusion of tramadol - a safe labour analgesia
}

\author{
Kalpana Kumari ${ }^{1 *}$, Neelam Swaroop ${ }^{1}$, Priya Sharma ${ }^{1}$, Shikha Seth ${ }^{1}$, \\ Vaibhav Kanti' ${ }^{1}$ Dinesh Kumar ${ }^{2}$
}

\begin{abstract}
${ }^{1}$ Department of Obstetrics \& Gynaecology, ${ }^{2}$ Department of Orthopaedics, Uttar Pradesh Rural Institute of Medical Science and Research, Saifai, Etawah-206130, U.P. India
\end{abstract}

Received: 18 May 2015

Accepted: 06 June 2015

\section{*Correspondence:}

Dr. Kalpana Kumari,

E-mail: doc.kalpana@yahoo.com

Copyright: (C) the author(s), publisher and licensee Medip Academy. This is an open-access article distributed under the terms of the Creative Commons Attribution Non-Commercial License, which permits unrestricted non-commercial use, distribution, and reproduction in any medium, provided the original work is properly cited.

\section{ABSTRACT}

Background: Tramadol has less maternal sedative effect and less neonatal depression, combines the mechanism of action of opioids and tricyclic antidepressants, now widely used for postoperative and obstetric analgesia. The aim the present study was to assess the efficacy and safety of intravenous infusion of tramadol as a safe analgesia for labour.

Methods: The study was conducted on hundred primigravida with vertex presentation in active phase of labour. The following points were noted, (1) the time of onset of pain relief; (2) the degree of pain relief. (3) Maternal and foetal adverse effects.

Results: Good relief of pain in 27 patient and moderate relief of pain in 16 patient and mild relief of pain in 7 patients was observed. The average time of onset in pain relief was 13 minutes. Majority of the parturients did not suffer from any adverse effects in our study.

Conclusions: The tramadol hydrochloride intravenous infusion is safe and effective analgesia for labour.

Keywords: Analgesia, Labour, Tramadol

\section{INTRODUCTION}

Advances in the field of labour analgesia have a long journey from the days of ether and chloroform in 1847 to the present day practice of comprehensive programme of labour pain management using evidence based medicine. The birth of the baby is one of the important and momentous events in the life of a women. Painless child birth and short duration labour has been the desire of every women and constant aim of the obstetrician unrelieved stress in labour increased plasma cortisol and catecholamine which may reduce uteroplacental blood flow increase sympathetic stimulation may lead to elevated levels of lactic acid and free fatty acids, which aggravates maternal metabolic acidosis further contributing to low of foetal $\mathrm{pH}$ and diminished fetal oxygenation. Therefore ideally every labour should be managed with some pain relieving measures.

There are several methods used for control of labor pain, which include various drugs like ether, Enflurane, Isoflurane, ketamine and opioid analgesics like Morphine,
Pethidine, Fentanyl via different routes e.g. inhalation anaesthesia, epidural anaesthesia, local anaesthesia patient controlled epidural and intravenous anaesthesia.

An ideal obstetric analgesic agent should be easy to administer with wide margin of safety, it should neither interfere uterine contraction nor have depressant effect on maternal or foetal respiratory or cardiovascular system before or after delivery. Bitsc et al. used in 1980 parentral analgesia with tramadol in 23 deliveries.

Tramadol has a very peculiar pharmacological profile and in many aspects it approaches the ideal one. It has less maternal sedative effective and less neonatal depression. Effect of Tramadol is the result of synergy between two different analgesic actions, i.e. tramadol binds weekly to the opioid receptors inhibiting the transmission of pain impulse and altering the pain perception.

Tramadol also reduces the reuptake of serotonin and noradrenaline in descending spinal inhibitory system and 
thereby enhancing the effectiveness of the inhibitory pathway.

Thus Tramadol combines the mechanism of action of opioids and tricyclic antidepressants, individually these actions are week but together they produce a powerful analgesia. Therefore it is now widely used for postoperative and obstetric analgesia.

\section{METHODS}

The present prospective study was conducted in our department of Obstetric and Gynaecology on the full term primigravida women from different socio economic classes. In June 2011- June 2013 at our tertiary care center U.P.R.I .I.M.S \& R. Saifai.

A total 100 cases were studied. 50 cases were received intravenous Tramadol and 50 cases were taken as control group who did not received any analgesia.

The inclusion criteria was primigravida with term gestation (37-41 weeks) without cephalopelvic disproportion in active phase of labor more than $3 \mathrm{~cm}$ dilation with well engaged cephalic pole and good uterine contractions i.e. (3-4 contractions per 10 minutes and each lasting for more than 45 seconds or more) and willing for analgesia were included in study.

Women with medical disorders as preeclampsia, eclampsia, heart disease, epilepsy, diabetes and psychiatric disorders were not included in the study. Further cases with obstetrical risks as cephalo pelvic disproportion, abnormal lie, multiple pregnancy and existing fetal distress preterm and post dated pregnancy, $\mathrm{Rh}$ incompatibility were excluded from the study. In the study groups cases; induction of analgesia was done by given inj Tramadol hydrochloride $100 \mathrm{mg}$ diluted in $10 \mathrm{ml}$ of normal saline intravenously slowly for 5-10 minutes and for maintaining analgesia continuous infusion of inj. Tramadol $100 \mathrm{mg}$ in $500 \mathrm{cc}$ of $5 \%$ dextrose was started at the rate of $10-12$ drops/minute or $30 \mathrm{ml} /$ hour and then adjusted according to patient response.

The following points were noted after Tramadol infusion-

a. Time of onset of pain relief.

b. Degree of analgesia was noted on a scale of 0-3:-

i. $0=$ No relief pain

ii. $1=$ Mild relief of pain

iii. $2=$ Moderate relief of pain

iv. $3=$ good relief of pain.

c. Mode of delivery

d. Maternal and fetal complication

e. Adverse effect of the drug used

f. Apgar score at 1 minute and 5minute

Statistical analysis was done using $\mathrm{z}$ test. $\mathrm{P}$ value $<0.05$ considered statically significant.

\section{RESULTS}

A total of 100 primigravida women were studied. 50 cases taken as control and 50 women received intravenous Tramadol in active phase of labour. Both groups were similar in term of weight, height and age group. No significant difference was detected in demographic profile (Table 1).

Table 1: Parturient demographic profile.

\begin{tabular}{|llll|}
\hline & $\begin{array}{l}\text { Tramadol } \\
\text { Gp }\end{array}$ & $\begin{array}{l}\text { Control } \\
\text { Gp }\end{array}$ & $\begin{array}{l}\text { P } \\
\text { value }\end{array}$ \\
\hline $\begin{array}{l}\text { Demographic } \\
\text { profile }\end{array}$ & $\begin{array}{l}\mathrm{n}=50 \\
\text { mean } \pm \text { SD }\end{array}$ & $\begin{array}{l}\mathrm{n}=50 \\
\text { mean } \pm \text { SD }\end{array}$ & \\
\hline $\begin{array}{l}\text { Mean age } \\
\text { (years) }\end{array}$ & $27.2 \pm 2.2$ & $27.1 \pm 1.9$ & $>0.05$ \\
\hline $\begin{array}{l}\text { Mean height } \\
(\mathrm{cm})\end{array}$ & $162.3 \pm 3.4$ & $161 \pm 2.1$ & $>0.05$ \\
\hline $\begin{array}{l}\text { Mean weight } \\
(\mathrm{kg})\end{array}$ & $76.8 \pm 10.3$ & $77.2 \pm 9.9$ & $>0.05$ \\
\hline $\begin{array}{l}\text { Mean } \\
\text { gestational age } \\
\text { (weeks) }\end{array}$ & $39.6 \pm 1.4$ & $39.5 \pm 1.0$ & $>0.05$ \\
\hline
\end{tabular}

The mean time of onset of analgesia was $13 \mathrm{~min}$. and mean duration of analgesia in study group was 4.22 hours.

All the parturients experienced varying degree of pain relief 27 women had good pain relief and 16 had moderate while 7 had mild pain relief of pain (Table 2)

Table 2: Degree of pain relief in study group.

\begin{tabular}{|ll|}
\hline Degree of pain relief & $\begin{array}{l}\text { Study group } \\
\mathbf{X}=50\end{array}$ \\
\hline 3- Good relief of pain & 27 \\
\hline 2- moderate relief of pain & 16 \\
\hline 1-Mild relief of pain & 7 \\
\hline 0-No relief of pain & 0 \\
\hline
\end{tabular}

$\mathrm{N}=$ Number of cases

$\mathrm{SD}=$ Standard deviation

NS = Not significant

The drugs used did not appear to influence either the observed duration or mode of delivery. Women receiving Tramadol had similar instrumental, vaginal and caesarean delivery rate as control group. While the mean duration of labour was shorten in Tramadol group compared to control group, although not to the significant level (Table 3).

Table 3: Effect on outcome of labour.

\begin{tabular}{|c|c|c|c|}
\hline $\begin{array}{l}\text { Labor } \\
\text { Characteristics }\end{array}$ & $\begin{array}{l}\text { Tramadol } \\
\mathrm{Gp} \\
\mathrm{n}=\mathbf{5 0}\end{array}$ & $\begin{array}{l}\text { Control } \\
\text { Gp } \\
n=50\end{array}$ & Significance \\
\hline $\begin{array}{l}\text { Normal Vaginal } \\
\text { delivery (N\%) }\end{array}$ & $45(90)$ & $43(86)$ & NS \\
\hline
\end{tabular}




\begin{tabular}{|llll|}
\hline $\begin{array}{l}\text { Instrumental } \\
\text { vaginal delivery } \\
\text { (N\%) }\end{array}$ & $3(6)$ & $4(8)$ & NS \\
\hline $\begin{array}{l}\text { Caesarian } \\
\text { delivery (N\%) }\end{array}$ & $2(4)$ & $3(6)$ & NS \\
\hline $\begin{array}{l}\text { Mean duration } \\
\text { of labor (hour } \pm \\
\text { SD) }\end{array}$ & $4.1 \pm 1.4$ & $\begin{array}{l}5.1 \pm \\
1.5\end{array}$ & NS \\
\hline
\end{tabular}

$\mathrm{N}=$ Number of cases

$\mathrm{SD}=$ Standard deviation

NS = Not significant

There is no significant difference in neonatal outcomes in both the groups (Table 4).

Table 4: Neonatal out come.

\begin{tabular}{|llll|}
\hline & $\begin{array}{l}\text { Tramadol } \\
\text { group }\end{array}$ & $\begin{array}{l}\text { Control } \\
\text { group }\end{array}$ & $\begin{array}{l}\text { P } \\
\text { value }\end{array}$ \\
\hline $\begin{array}{l}\text { Mean apgar } \\
\text { score < 5 at } \\
1 \text { min }\end{array}$ & 5 & 6 & NS \\
\hline $\begin{array}{l}\text { Mean apgar } \\
\text { score < } 7 \text { at } \\
5 \text { min. }\end{array}$ & 3 & 4 & NS \\
\hline $\begin{array}{l}\text { Birth weight } \\
\text { in kg }\end{array}$ & 2.67 & 2.83 & NS \\
\hline $\begin{array}{l}\text { N.I.C.U. } \\
\text { admission }\end{array}$ & 2 & 3 & NS \\
\hline
\end{tabular}

Frequency of drug related side effects were observed in study group. All these minor effects subsided after 12 14 hrs (Table 5)

Table 5: Side effects and complication in study group.

\begin{tabular}{|ll|}
\hline Maternal Morbidity & $\mathbf{n}=50$ \\
\hline No side effect & $41(82 \%)$ \\
\hline Tachycardia $>100 /$ min. & $01(2 \%)$ \\
\hline Nausea & $01(2 \%)$ \\
\hline Vomiting & $02(4 \%)$ \\
\hline Headache & $01(2 \%)$ \\
\hline Drowsiness & $02(4 \%)$ \\
\hline Palpitation & $02(4 \%)$ \\
\hline
\end{tabular}

\section{DISCUSSION}

Pain is the most important human experience and also is most complex one. Pain may result in harmful physiological responses in both the mother and the fetus. In addition pain during child birth may result in the experience being distressing and discomfort for the parturient.

There are several methods and drugs used for pain relief in labor. Though it provides a very effective analgesia, epidural administration remains the least utilized method in labour care facilities in countries like India because of dependence on availability of anaesthesiologist involved cost of equipment and monitoring.

Prasertsawal $^{2}$ et al. 1986 observed the $100 \mathrm{mg}$ tramadol give satisfactory to good effect in 78 patient. However suvonnakote $^{3}$ et al 1986 reported that 59 patient did not obtain adequate analgesia with tramadol.

Nawani ${ }^{4}$ et al., 1996 observed excellent to average pain relief with tramadol in 80 cases while Sarkar and Mukhopadhyay $^{5} 1997$ observed satisfactory pain relief in $13 \%$ in our study mean onset of analgesia was 13 minute and effect lasted for 4.22 hours in present study. While husslein ${ }^{6}$ et al., 1986 concluded that distinct analgesic effect was observed after 10 minute and lasted for 2 hours.

Bitsch et al 1980 also observed that tramadol has no effect on duration and intensity of uterine contraction.

Tramadol hydrochloride is a sympathetic analogue of codeine, suggested to be equally effective analgesic and is cheaper it may be preferred over other opioids as it is associated with less sedation in our study.

All the parturient experienced varying degree of pain relief $27 \%$ of the parturient had good pain relief earlier studies by Nagaria Triptiet ${ }^{7}$ al observed $37 \%$ good pain relief in labor. The duration of analgesia lasted for 4 hours in our study, while Thakur Ratna ${ }^{8}$ et al reported 3.96 hours.

The drug use did not appear to influence either observed duration or mode of delivery woman receiving Tramadol had similar instrumental vaginal and caesarean delivery rates as control.

\section{CONCLUSION}

After close analysis of observation we conclude that tramadol is an effective and acceptable analgesia in labour if given in adequate doses as an intravenous infusion provided' criteria for selection of patients are maintained.

In addition tramadol given better pain relief, shorten the labour period and it is safe for both mother and baby.

In view of negligible maternal and foetal side effects and it may be used as a simple valuable cost effective remedy for painless labour.

\author{
Funding: No funding sources \\ Conflict of interest: None declared \\ Ethical approval: The study was approved by the \\ Institutional Ethics Committee
}




\section{REFERENCES}

1. Bitsch M, Emmrich J, Hary J, Lippach G, Rindt W. Geburtshilfliche analgesic mit tramadol. Fortschritte der Medizin. 1980;16:632-4.

2. Prasertsawat PO, Herabutya Y, Chaturachinda R. Obstetric analgesia. Current therapeutic research.1986;40:1022-9.

3. Suvonnakote $\mathrm{T}$, Thitadilok $\mathrm{W}$, Atisook R. pain relief during labour. J Med Assoc Thailand. 1986; 69:575-80.

4. Nawani M, Sharma S, Nawani DP, et al. U.P. Chapter of obstetrics and gynecology. 1996;2:41.

5. Sarkar B, Mukhopadhyay AK. Tramadol hydrochloride in dysfunctional labour - A clinical trial. J Obstet Gynecol India. 1997;47:42-8.

6. Husslein P, Kuvista E, Egarter C. Obstetrical analgesia with tramadol, result of a prospective randomized comparative study with pethidine. Zeitschrift Gegrtshilf umb perinatolfgie. 1987;191:234-7.

7. Nagaria T, Achaya J. Pain relief in labour-tramadol versus pentazocine. $\mathrm{J}$ Obstet Gynecol India. 2006;56(5):406-9.

8. Thakur R, Patidar R. Comparative study of transcutaneous electrical nerve stimulation (TENS) and tramadol hydrochloride for pain relief in labor. $\mathbf{J}$ Obstet Gynecol India. 2004;54:346-50.

9. Jaitley A, Singh S, Srivastava U, et al. A comparison between epidural and IV tramadol for painless labor and effect on perinatal outcome. J Obstet Gynaecol India. 2011;61:42-7.

Cite this article as: Kumari K, Swaroop N, Sharma P, Seth S, Kanti V, Kumar D. Intravenous infusion of tramadol - a safe labour analgesia. Int J Reprod Contracept Obstet Gynecol 2015;4:1044-7. 